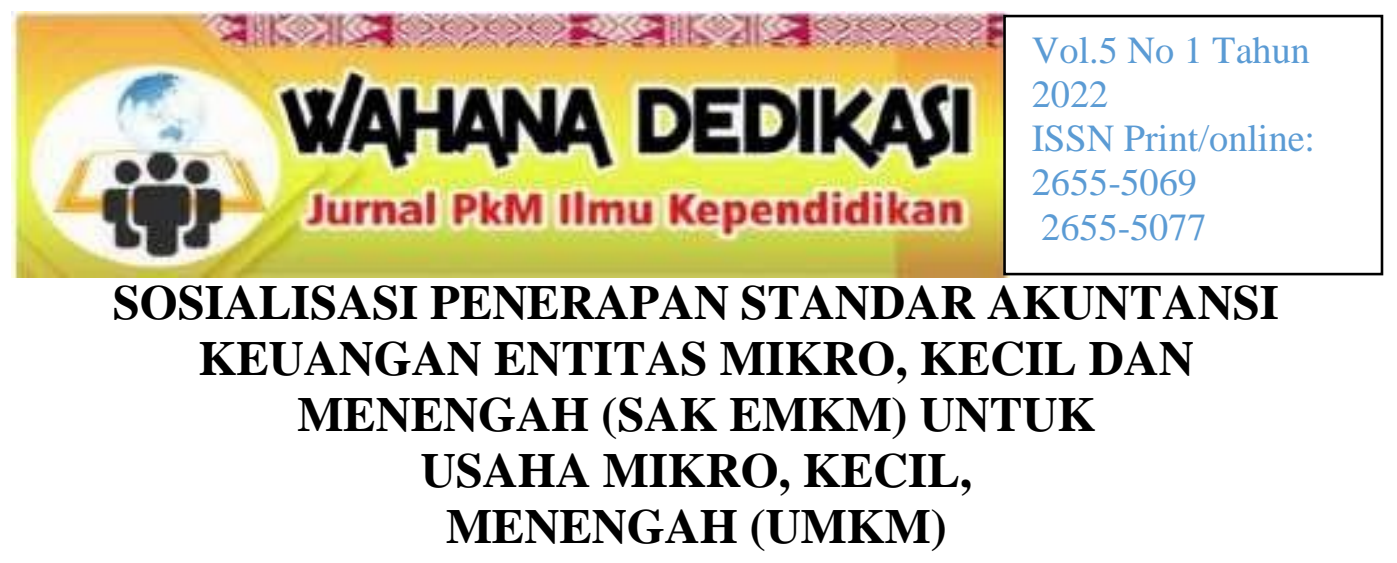

\author{
Rina Tjandrakirana ${ }^{1}$, Ermadiani ${ }^{2}$, Anton Indra Budiman ${ }^{3}$ \\ Program Studi Akuntansi Universitas Sriwijaya, $a^{1,2,3,4}$ \\ rinatjandrakirana@yahoo.com ${ }^{1}$,ermadiani@yahoo.co.id ${ }^{2}$, anton.indra@unsri.ac.id ${ }^{3}$
}

\begin{abstract}
Abstrak
Kegiatan yang dilaksanakan di desa Kerinjing Kabupaten Ogan Ilir Sumatera Selatan ini ditujukan untuk UMKM yang terdapat di desa tersebut. Seperti pada umumnya UMKM di Indonesia, pembukuan yang dibuat oleh UMKM di desa Kerinjing masih sangat sederhana dan cenderung mengabaikan kaidah standar yang berlaku. Dengan semakin berkembangnya usaha, UMKM dituntut untuk berhubungan dengan pihak eksternal perusahaan. Misalnya untuk meningkatkan permodalan, UMKM akan berhubungan dengan institusi keuangan. Institusi keuangan biasanya akan mensyaratkan laporan keuangan untuk menilai kelayakan kredit dari UMKM. UMKM harus menyediakan laporan keuangannya dengan baik sesuai standar yang berlaku. Untuk membantu UMKM, Dewan Standar Akuntansi Keuangan (DSAK) IAI telah mengesahkan SAK EMKM pada 24 Oktober 2016. SAK EMKM ini dibuat sederhana agar menjadi standar akuntansi dan keuangan yang mudah dipahami oleh pelaku UMKM di Indonesia. Tujuan kegiatan ini agar pelaku UMKM di desa Kerinjing mampu memahami SAK EMKM, mampu menerapkan SAK EMKM dalam penyusunan laporan keuangan dan mampu menyusun laporan keuangan sesuai SAK EMKM. Kegiatan ini dilakukan dengan cara memberikan pemahaman tentang SAK EMKM, memberikan pengetahuan tentang penerapan SAK EMKM dalam penyusunan laporan keuangan dan memberikan pendampingan dalam penyusunan laporan keuangan sesuai SAK EMKM untuk pelaku UMKM di desa Kerinjing.

Kata kunci: Sosialisasi, Penerapan, SAK EMKM, UMKM, Laporan Keuangan.
\end{abstract}

\begin{abstract}
This activity, which was carried out in the village of Kerinjing, Ogan Ilir Regency, South Sumatra, was aimed at MSMEs in the village. As in general UMKM in Indonesia, the bookkeeping made by UMKM in Kerinjing village is still very simple and tends to ignore the applicable standard rules. With the growing business, UMKM are required to relate to external parties of the company. For example, to increase capital, UMKM will relate to financial institutions. Financial institutions will usually require financial reports to assess the creditworthiness of UMKM. UMKM must provide their financial reports properly according to applicable standards. To help UMKM, the Financial Accounting Standards Board (DSAK) IAI has ratified SAK EMKM on October 24, 2016. SAK EMKM is made simple so that it becomes an accounting and financial standard that is easily understood by UMKM actors in Indonesia. The purpose of this activity is so that UMKM actors in Kerinjing village are able to understand SAK EMKM, are able to apply SAK EMKM in preparing financial reports and are able to prepare financial reports according to SAK EMKM. This activity is carried out by providing an understanding of SAK EMKM, providing knowledge about the application of SAK EMKM in the preparation of financial reports and providing assistance in preparing financial reports according to SAK EMKM for UMKM actors in Kerinjing village.
\end{abstract}

Keywords: Socialization, Implementation, SAK EMKM, UMKM, Annual Report

Artikel Diterima : 27-11-2021 Artikel disetujui tanggal:10-01-2022 Artikel Diterbitkan : 16-01-2022

Corresponden Author:Rina Tjandrakirana e-mail:rinatjandrakirana@yahoo.com

DOI: http://dx.doi.org/10.31851/dedikasi.v5i1.6703 do 


\section{WAHANA DEDIKASI}

PENDAHULUAN

Akuntansi merupakan bagian terpenting dalam perkembangan bisnis di Indonesia, baik usaha kecil menengah maupun bisnis skala besar. Pentingnya akuntansi mensyaratkan pelaku usaha memahami apa itu akuntansi dan bagaimana metode akuntansi dari setiap bidang usaha.

Usaha Mikro Kecil dan Menengah (UMKM) memiliki peran yang cukup penting dalam menggerakkan perekonomian di Indonesia, dalam hal pertumbuhan dan penyerapan tenaga kerja di Indonesia. Sehingga dibutuhkan dukungan dari semua pihak untuk mengembangkan dan mewujudkan UMKM yang maju, mandiri dan modern termasuk memiliki akses pendanaan yang semakin luas ke sektor perbankan (SAK-EMKM IAI, 2018).

Akan tetapi para pelaku UMKM pada umumnya kurang memahami penyusunan laporan keuangan yang benar dan perlu dibekali tentang pentingnya laporan keuangan suatu bisnis. Sistem pembukuan UMKM umumnya masih sangat sederhana dan cenderung mengabaikan kaidah administrasi keuangan yang standar (baku).

Padahal laporan keuangan yang akurat dan baku akan banyak membantu mereka dalam upaya pengembangan bisnisnya secara kuantitatif maupun kualitatif. Penyusunan Laporan Keuangan yang baik yang sesuai dengan Standar Akuntansi Keuangan Entitas Mikro Kecil Menengah (SAK EMKM) bukan hanya dibutuhkan pada saat berhubungan dengan mitra usaha atau lembaga keuangan, tetapi juga dibutuhkan untuk pendataan aset dan omzet para pelaku UMKM (Dimyati, 2019). Demikian juga ketika UMKM akan mengikuti lelang pengadaan barang maupun jasa yang diadakan oleh pihak rekanan, pihak rekanan biasanya akan meminta laporan keuangan sebagai syarat kelengkapan administratif.

Ikatan Akuntan Indonesia (IAI) telah menerbitkan SAK EMKM untuk membantu UMKM agar menjadi lebih transparan, efisien dan akuntabel. Aspek itu selama ini menjadi tantangan terbesar UMKM dalam mengakses permodalan dari institusi keuangan, sehingga menghambat pertumbuhan dan peran UMKM sebagai penopang ekonomi Indonesia di masa depan.

Dewan Standar Akuntansi Keuangan (DSAK) IAI telah mengesahkan SAK EMKM pada 24 Oktober 2016. SAK EMKM ini dibuat sederhana agar menjadi standar akuntansi dan keuangan yang mudah dipahami oleh pelaku UMKM di Indonesia. SAK EMKM diharapkan dapat membantu entitas dalam melakukan transisi dari pelaporan keuangan dasar kas ke pelaporan keuangan dasar akrual.. Penerbitan SAK EMKM ini juga diharapkan dapat menjadi salah satu pendorong literasi keuangan bagi UMKM Indonesia sehingga memperoleh akses yang semakin luas untuk pembiayaan dari industri perbankan. SAK EMKM ini berlaku efektif sejak 1 Januari 2018 dengan penerapan dini diperkenankan.

Desa Kerinjing merupakan salah satu dari 241 desa yang ada di wilayah Kabupaten Ogan Ilir dan 


\section{WAHANA DEDIKASI}

salah satu dari 19 Desa di wilayah Kecamatan Tanjung Raja yang terletak $7 \mathrm{Km}$ ke arah Barat dari Ibu Kota Kecamatan dan $13 \mathrm{Km}$ kearah Timur dari Ibu Kota Kabupaten dan mempunyai luas $\pm 3,00 \mathrm{Km}^{2}$.

Desa Kerinjing terbagi menjadi 2 dusun yang dipimpin oleh masing-masing Kepala Dusun. Desa Kerinjing, memiliki jumlah penduduk pada akhir tahun 2017 sebanyak 1.307 jiwa, terdiri dari 665 laki-laki dan 642 perempuan (BPS 2017). Dari bidang ekonomi potensi desa dapat dilihat dari usaha-usaha keluarga seperti pembuatan pakaian (penjahit), usaha angkutan umum, usaha kemplang tunu dan warung-warung sembako. Dari hasil wawancara dengan Kepala Desa Kerinjing, terdapat kurang lebih 50 UMKM di desa Kerinjing.

Semakin berkembangnya usaha, menuntut UMKM untuk berhubungan dengan pihak eksternal perusahaan. Misalnya untuk meningkatkan permodalan, UMKM akan berhubungan dengan institusi keuangan. Institusi keuangan biasanya akan mensyaratkan laporan keuangan untuk menilai kelayakan kredit dari UMKM. Sehingga dengan berkembangnya usaha, menuntut UMKM untuk menyediakan laporan keuangannya dengan baik sesuai standar yang berlaku.

\section{Pada Pengabdian Kepada}

Masyarakat Fakultas Ekonomi Universitas Sriwijaya Tahun 2019 dan 2020 telah dilakukan pelatihan dan pendampingan penyusunan pembukuan sederhana serta penyusunan laporan arus kas untuk usaha kecil menengah di desa Kerinjing. Akan tetapi dari hasil pengabdian terdahulu, para pelaku UMKM belum semuanya bisa menyusun laporan keuangan yang sesuai dengan standar akuntansi. Untuk itu pada pengabdian kali ini, akan dilaksanakan sosialisasi penerapan SAK EMKM dalam penyusunan laporan keuangan UMKM di desa Kerinjing.

Dari analisis situasi yang dijelaskan di atas, dapat dirumuskan masalah yang dihadapi oleh pelaku UMKM di desa Kerinjing adalah mereka belum mengetahui serta memahami standar akuntansi keuangan untuk penyusunan laporan keuangan UMKM yaitu standar akuntansi keuangan entitas mikro, kecil, menengah (SAK EMKM).

Tujuan kegiatan pengabdian kepada masyarakat berupa sosialisasi penerapan Standar Akuntansi Keuangan Entitas Mikro, Kecil, Menengah (SAK EMKM) untuk UMKM di desa Kerinjing ini antara lain agar:

a. Peserta mampu memahami SAK EMKM

b. Peserta mampu memahami pentingnya penyusunan laporan keuangan berdasarkan SAK EMKM

c. Peserta mampu menyusun laporan keuangan sesuai SAK EMKM

d. Peserta mampu menggunakan laporan keuangan berdasarkan SAK EMKM untuk mengambil keputusan

\section{BAHAN DAN METODE}

Bahan dan metode pelaksanaan kegiatan pengabdian ini 


\section{W/AHANA DEDIKASI}

kami laksanakan dengan rincian sebagai berikut:

\section{Metode Pelaksanaan}

kepada Pelatihan yang diberikan menggunakan metode pembelajaran pedagogi. Pembicara memberikan pelatihan dengan monolog kemudian dilanjutkan dengan cara dialog dua arah antara narasumber dengan peserta. Proses dialog merupakan proses pemberian materi dan arahan kepada peserta dengan cara berdiskusi, bertatap muka dan curah pendapat terhadap kasus dan materi serta berbagai arahan narasumber kepada perserta pelatihan.

Pembelajaran monolog dilanjutkan dengan proses dialog dan pendampingan. Proses pendampingan adalah kegiatan yang mengikutsertakan peserta dengan instruktur secara langsung untuk mengerjakan kegiatan yang dilaksanakan.

\section{Bahan Pelaksanaan Kegiatan}

Bahan pelaksanaan kegiatan pengabdian ini akan dilakukan melalui dua tahapan yaitu tahap persiapan dan tahap pelaksanaan.

\section{Tahap Persiapan}

Pada tahap ini hal yang dilakukan adalah mempersiapkan segala sesuatu yang berkaitan dengan kegiatan pengabdian, termasuk mempersiapkan referensi yang terkait dengan SAK EMKM, mengumpulkan dan merangkum materi yang akan disampaikan. Pada tahap ini juga disiapkan contoh pembuatan laporan keuangan sesuai SAK EMKM.

2. Tahap Pelaksanaan

Tahap ini akan dibagi menjadi 3 bagian, yaitu pengenalan (sosialisasi), penerapan dan evaluasi. Pada tahap pengenalan, peserta akan diberikan pemahaman mengenai SAK EMKM. Pada tahap berikutnya yaitu penerapan, kami akan membimbing peserta untuk mulai melakukan penerapan SAK EMKM dalam penyusunan laporan keuangan. Pada tahap terakhir, akan dilakukan evaluasi terhadap penyusunan laporan keuangan yang telah diseuaikan dengan standar.

Keberhasilan kegiatan ini akan dievaluasi berdasarkan tujuan yang ingin dicapai. Kegiatan ini juga akan diakhiri dengan permintaan respon dalam bentuk kuesioner untuk feedback kegiatan di masa yang akan datang

\section{HASIL DAN PEMBAHASAN}

Kegiatan pengabdian Sosialisasi penerapan Standar Akuntansi Keuangan Entitas Mikro, Kecil, Menengah (SAK EMKM) untuk Usaha Mikro, Kecil, Menengah (UMKM) di desa Kerinjing ini kami lakukan berkesinambungan dengan pengabdian di tahun-tahun sebelumnya. Sebelumnya kami telah memberikan pelatihan dan pendampingan penyusunan pembukuan sederhana dan penyusunan laporan arus kas untuk UMKM. Pada kegiatan pengabdian kali ini diikuti oleh 27 (dua puluh 


\section{WAHANA DEDIKASI}

tujuh) peserta yang terdiri dari para pelaku UMKM di desa Kerinjing, dimana kegiatan ini dilaksanakan selama tiga hari.

Pada hari pertama acara dibuka dengan kata sambutan dari Kepala Desa Kerinjing yaitu Bapak Faisal Kimi. Setelah acara pembukaan, kemudian dilanjutkan dengan penyampaian materi yang disampaikan oleh nara sumber dengan topik sosialisasi SAK EMKM. Setelah itu dilanjutkan dengan penjelasan tentang penyusunan laporan keuangan sesuai SAK EMKM.

Penyampaian

materi

dilakukan dengan menggunakan proyektor dan membagikan makalah kepada para peserta agar mereka dapat memahami secara utuh materi yang diberikan. Para peserta cukup antusias menyimak dan memperhatikan bagaimana penjelasan tentang SAK EMKM dan penyusunan laporan keuangan UMKM sesuai SAK EMKM.

Setelah penyampaian materi oleh narasumber, tim mengajak peserta untuk berdiskusi tentang materi yang diberikan. Banyak pertanyaan yang disampaikan oleh peserta, mengenai hal-hal yang belum dipahami terkait materi yang diberikan.

Pada hari kedua, peserta diberikan latihan dan pendampingan cara menyusun laporan keuangan sesuai SAK EMKM. Pada umumnya mereka sudah cukup memahami cara membuat pembukuan sederhana, karena pada pengabdian tahun-tahun sebelumnya, kami telah memberikan pelatihan dan pendampingan tentang penyusunan pembukuan sederhana.
Pada hari ketiga tim melakukan evaluasi atas kegiatan pengabdian ini. Dari dua hari kegiatan sebelumnya, peserta telah cukup memahami tentang pentingnya SAK EMKM dan cara menyusun laporan keuangan berdasarkan SAK EMKM, untuk kelangsungan usahanya serta untuk pengembangan usahanya.

Pada saat melakukan kegiatan pengabdian kepada masyarakat ini, ada beberapa kendala yang kami hadapi, di antaranya adalah para pelaku UMKM atau peserta pelatihan banyak yang belum memahami SAK EMKM dan pentingnya laporan keuangan yang disusun sesuai SAK EMKM.

Laporan keuangan untuk UMKM yang disusun berdasarkan SAK EMKM sangat berguna apabila UMKM tersebut akan berhubungan dengan pihak eksternal perusahaan. Dengan semakin berkembangnya usaha, UMKM dituntut untuk berhubungan dengan pihak eksternal perusahaan. Misalnya untuk meningkatkan permodalan, UMKM akan berhubungan dengan institusi keuangan (perbankan atau Lembaga keuangan lainnya). Institusi keuangan tersebut biasanya akan mensyaratkan laporan keuangan untuk menilai kelayakan kredit dari UMKM. UMKM harus menyediakan laporan keuangannya dengan baik sesuai standar yang berlaku.

Para pelaku UMKM di desa Kerinjing dalam melakukan usahanya pada umumnya hanya membuat pembukuan sederhana, bahkan ada yang belum membuat pembukuan. Pada awalnya mereka mengalami kesulitan dalam memahami SAK EMKM dan penyusunan laporan 


\section{W/AHANA DEDIKASI}

keuangan berdasarkan SAK EMKM.

Akan tetapi setelah diberikan sosialisasi, pelatihan dan pendampingan mengenai proses penyusunan laporan keuangan berdasarkan SAK EMKM, mereka dapat memahami bagaimana pentingnya SAK EMKM dan penyusunan laporan keuangan sesuai SAK EMKM untuk kelangsungan dan pengembangan usahanya.

Di bawah ini disampaikan foto-foto kegiatan pengabdian kepada masyarakat Sosialisasi Penerapan Standar Akuntansi Keuangan Entitas Mikro, Kecil, Menengah (SAK EMKM) untuk Usaha Mikro, Kecil, Menengah (UMKM) di desa Kerinjing:

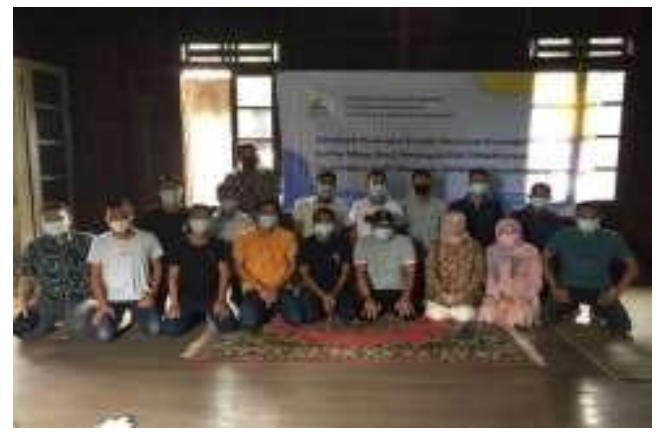

Gambar 1. Tim pengabdian bersama peserta pada saat pembukaan

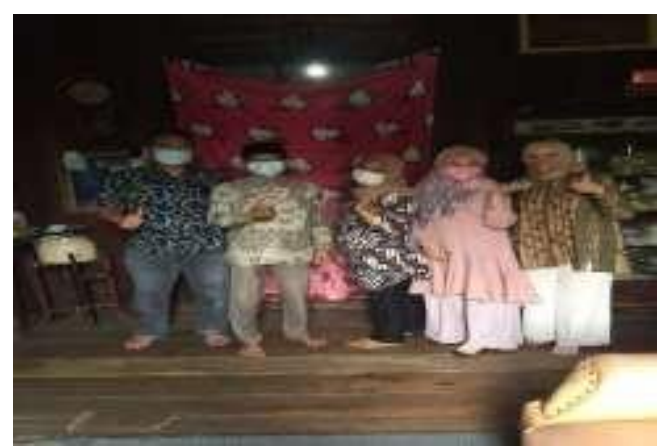

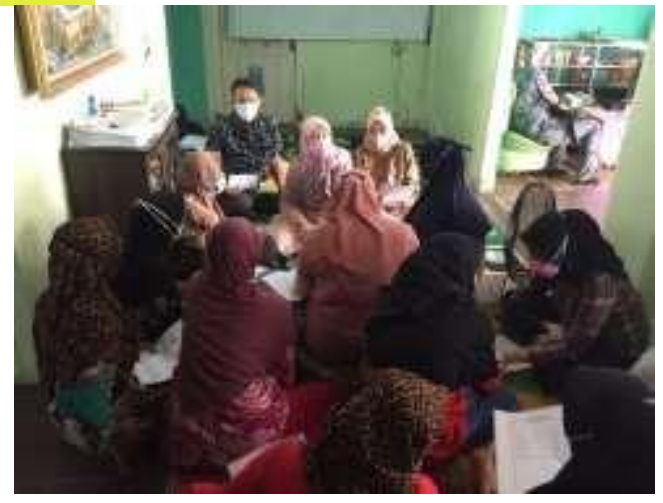

Gambar 3. Tim Pengabdian sedang mempresentasikan materi

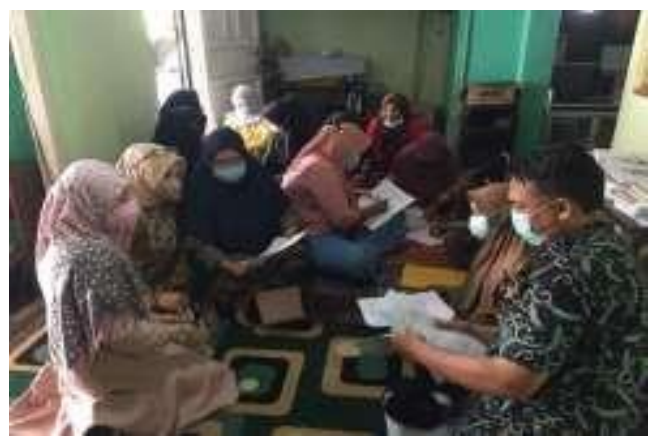

Gambar 4.Tim berdiskusi dengan peserta

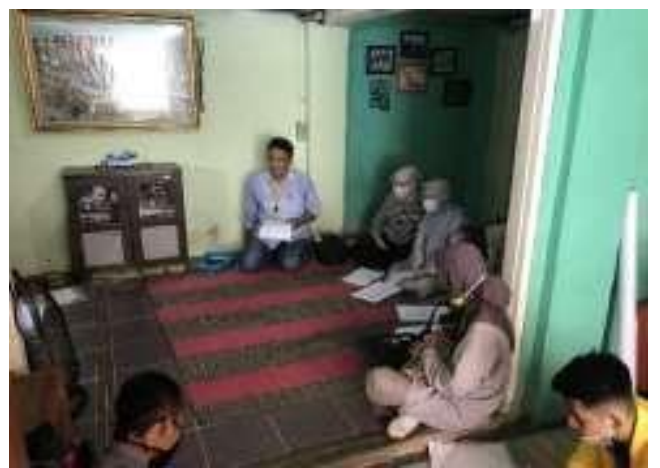

Gambar 5. Para Peserta Menyimak Isi Materi

Gambar 2. Sambutan dari Kepala Desa Kerinjing 


\section{W/AHANA DEDIKASI}

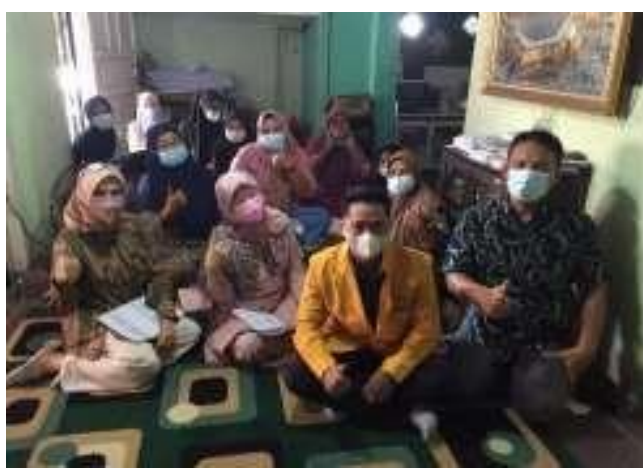

Gambar 6. Bersama mahasiswa yang terlibat dalam pengabdian



Gambar 7. Pserta mengerjakan latihan yang diberikan tim



Gambar 8. Tim Pengabdian bersama mahasiswa yang terlibat

\section{KESIMPULAN}

Dari pelaksanaan kegiatan pengabdian pada masyarakat ini, dapat disimpulkan:
1. Kegiatan pengabdian ini dilaksanakan untuk memberikan solusi terhadap permasalahan yang dihadapi oleh para pelaku UMKM khususnya di desa Kerinjing.

2. Para peserta mengikuti pelatihan ini dengan antusias dan aktif, hingga kegiatan ini berakhir untuk mendapatkan pemahaman yang memadai dan merasakan manfaat pelatihan mengenai penyusunan laporan keuangan berdasarkan SAK EMKM untuk UMKM di desa Kerinjing.

3. Kegiatan pengabdian ini mampu meningkatkan pengetahuan dan kesadaran peserta bahwa penyusunan laporan keuangan sesuai SAK EMKM ini bermanfaat bagi kemajuan usahanya, untuk efisiensi dan efektivitas usaha, perkembangan usaha dan peluang usaha lainnya.

\section{DAFTAR PUSTAKA}

Agung Prajanto dan Ira Septriana. 2018. Implementasi Penerapan SAK EMKM serta Dampaknya pada Kualitas Pelaporan Keuangan UMKM (Studi Kasus Pada UMKM se Kota Semarang). Vol.20No.2. P. 79-89. ISSN 1693-928X

Carl S. Warren, James M. Reeve, Jonathan E. Duchac, Ersa Tri Wahyuni, Amir Abadi Jusuf, 2017. Accounting Volume 1, Penerbit Erlangga. Cengage Learning.

Hermi Sularsih, Amar Sobir. 2019. Penerapan SAK EMKM 


\section{WAHANA DEDIKASI}

Dalam Penyusunan Laporan

Keuangan pada UMKM

Kecamatan Lowokwaru Kota

Malang, JAMSWAP; Jurnal

Akuntansi dan Manajemen.

ISSN: 2086-3659 (P) Volume

4 Nomor 4 (2019): 10-16

Ikatan Akuntan Indonesia. 2015.

Pedoman Standar Akuntansi

Keuangan No.1 Revisi 2009

Ikatan Akuntan Indonesia, 2018.

Standar Akuntansi Keuangan

Entitas Mikro, Kecil dan

Menengah.

Undang-Undang Republik Indonesia. 2008. Undang-Undang Nomor 20 Tahun 2008 tentang Usaha Mikro, Kecil dan Menengah.

Yananto Mihadi Putra. 2018.

Pemetaan Penerapan Standar Akuntansi Keuangan EMKM pada UMKM di Kota Tangerang Selatan. Profita : Komunikasi Ilmiah Akuntansi dan Perpajakn. Volume 11 No.2. P. 201-2017.p-ISSN: 2086-7662. E-ISSN: 26221950 